\title{
Science and Technology Course in Educational Information Network a Review on Videos
}

\author{
M. Furkan Bayar ${ }^{1}$, Murat Kurt ${ }^{2, *}$, M. Akif Haşıloğlu ${ }^{3}$ \\ ${ }^{1}$ Erzurum İl Milli Eğitim Müdürlüğü (MEB), Erzurum, Turkey \\ ${ }^{2}$ Primary School Teaching, Faculty of Education, Amasya University, Turkey \\ ${ }^{3}$ Primary School Teaching, Faculty of Education, Ağrı İbrahim Çeçen University, Turkey
}

Copyright $\bigcirc 2018$ by authors, all rights reserved. Authors agree that this article remains permanently open access under the terms of the Creative Commons Attribution License 4.0 International License

\begin{abstract}
The FATIH project is a project put in place by a protocol signed between the Ministry of National Education and the Ministry of Transport in order to obtain the highest level of efficiency and equal opportunities in education and training activities. Today, remote education applications have become compulsory in order to reach the rapidly changing and developing information network more easily and effectively. For this reason, an increase in distance education program designs has been observed in order to provide meaningful learning in Science and Technology course. The key role in increasing opportunities in education and improving the technology (FATIH PROJECT) is educational e-content applications. To this end, the Education Information Network (EBA) online social education platform has been established, which is equal opportunity in the basic principle education. Some of the contents in EBA, along with visual and interactive material, audio files and animations, have become the most important elementary videos of this platform. It was aimed to study science and technology course videos with a systematic understanding. Thus, it has been investigated how these videos contribute to the scope of the "FATIH Project". It is a descriptive study to examine the science and technology course videos in EBA systematically in terms of various variables. In the study, document review method was used from qualitative research methods. Science and Technology course videos analyzed in this study include Science and Technology course presentations for 5th, 6th, 7th, and 8th grade students who are available on EBA on July 28th, 2017. 433 course videos were reviewed by each of the researchers in terms of eight (8) pre-determined questions that were repeated five times. The conclusions reached were finalized in accordance with the sub-objectives.
\end{abstract}

Keywords Educational Information Network, Science and Technology Course Videos, Document Analysis

\section{Introduction}

In today's educational activities, expectations have changed and the effective efforts of learners and learners have come to the forefront. Especially technological progress has been closely linked to education and more meaningful learning has come to the forefront [1].

In the past, day-to-day educational environments have been in continuous transformation, and the classes are now equipped with technological tools and intended to be used effectively [2].

Constructivism from rooted psychology and philosophy has begun to direct the basic structure of the Turkish education system. Constructivism is a strategy that deals with the nature of knowledge and how information is structured [3]. It is based on how knowledge is transferred and interpreted away from memorizing learning $[4,5]$.

Education is based on the experience of the individual. When new knowledge is compared with old knowledge, meaningful learning takes place [6]. The student should be active and the teacher should assume the role of guide [7]. The student does not specify what they will do in the direction of specific goals and the individual moves in the direction of his own opportunities $[8,9]$.

Science-Technology-Society-Environment (FTTÇ) learning areas have been determined in order to realize the vision that all students should be science literate in the Science and Technology Course Teaching Program (Physics, Technology, Society-Environment (FTTÇ)) with the subjects of Live and Life, Matter and Change, Physical Events and Earth and Universe [10].

While training materials are being prepared, it is more appropriate to prepare the gains in a simple system and in a specific system [11]. For this reason, a taxonomy is needed to determine and prepare behaviors that are desired to be given to individuals [12]. The taxonomy that has been used most effectively since its publication in 1956 belongs to Bloom [13]. Educational e-content in the EBA should be prepared by looking at the characteristics of the Bloom 
taxonomy that is appropriately adapted;

In the memorandum of memory, the return of knowledge and the ability to reconfigure [14]; At the understanding stage, the ability of the student to explain the information and transform it into a new narrative form [15]; At the application level, transfer of skills to a new problem situation; The ability to segment, differentiate, and compare information, events, or ideas at the level of analysis [16]; During the evaluation phase; the ability to reach a judgment by putting certain criteria [17], and the ability to put on a new unique product in the creation phase is measured [18].

Our education system has to be in line with world standards as well as national. Indeed, one of our national development goals is; social development, increasing the level of prosperity, attaching importance to science and technology, and expanding R \& D activities is to be a competitive and productive country at global level [19]. In line with this aim, the Ministry of Transport and the Ministry of Transport, Maritime Affairs and

Communication developed the project "Improvement of Opportunity Techniques to Improve Opportunities", which was coded as "FATIH" on 22.10.2010. The FATIH project in education consists of five main components [20].

In order to obtain effective yield from these equipment mentioned in the classrooms by Ministry of National Education, teachers were asked to prepare educational e-content from in-service training seminars [21]. One of the most important of these educational e-contents is the Education Information Network (EBA).

EBA enabled students to become more active, more enjoyable of lessons and more productive learning [22]. Teachers agreed that the lessons were more constructive and positive with EBA [23].

While preparing EBA; the guidance principle is kept in the foreground, equipped with the items to respond to the needs, the effective communication between the social network of the students and the students themselves or the student teacher is given priority, the aim is to construct rather than to receive the information directly, is a cognitive and social network that is designed to appeal [24].

Individuals can be taught science literacy to improve problem solving, social skills and collaborative skills in daily life [25].

Some studies on EBA found the following findings;

Aktay and Keskin [26], in their work on EBA, they pointed out that the system created a good social environment for stakeholders. It provides e-content such as news, video, audio, visuals, documents, books and magazines to stakeholders and is useful.

Keles, Öksüz and Bahçekapılı [27], they applied to teachers' views on the use of educational information network. As a result of the study; it was determined that the teachers who participated in the survey had positive opinions against EBA, and were particularly satisfied with e-content. Findings are also among the findings of all positive thoughts as well as negative thoughts and concerns about the use of these technologies, such as teacher training and provision of content.

Tüysüz and Çümen [28], they applied to student opinions on the use of educational information network. Findings from the research indicate that the site is a useful site for the students to prepare for the exams, to reinforce the topics of the EBA website, and to make the site interesting in terms of narrative, educational games / activities, tests and videos. They also stated that the site contributes to increasing the successes, making the subject revolutions and testing solutions. In addition to this, they sometimes reported problems with not accepting passwords and making mistakes even though they did not have difficulty in entering the site. When they use the site, they stated troubles such as not opening the videos slowly, opening the homework, resetting the scores and resetting the scores. Students also believe that more games / entertainment, test and subject content should be added to the site.

Pala, Arslan and Özdinç [29], in their work on authentic tasks, eye tracking and usability, the videos in the EBA stated that the website was unusable and that they had trouble with design and content.

Ateş, Çerçi and Derman [30], in their work with EBA, they stated that this platform would support effective learning, but they pointed out that there were some shortcomings. When they examined the videos related to the Turkish lesson, they found that the students did not match the class levels. The number of views of videos is low.

\subsection{The Purpose of the Research}

The purpose of the study is to examine systematically the video contents in terms of various variables such as learning areas, duration, interaction characteristics, teaching / learning strategies, and science and technology course in EBA. Thus, it is aimed to present the properties of these electronic contents used in Science and Technology courses in terms of science and technology teaching and to contribute to its proper use for its purpose.

Depending on this reason in the study, the following questions were searched:

1. What is the distribution of science and technology course video materials according to classes in EBA?

2. How long is the course length of Science and Technology course video material in EBA?

3. How is the science and technology course in EBA distributed according to the number of watched video materials?

4. What is the science and technology course in EBA that is appropriate for the grade level of the video material in terms of the distribution of the course? 
5. Which learning area is included in the science and technology curriculum in the Science and Technology course videos in EBA?

6. Which teaching strategies have been used for video materials in the EBA?

7. What is the distribution of Science and Technology course videos in the EBA, according to the bloom taxonomy of the achievements students will receive?

8. Which teaching techniques are used in the videos in the EBA?

\section{Method}

This study is a descriptive study to examine systematically the videos of science and technology course in EBA. In the study, the method of document examination was used in qualitative research methods. Detailed analysis of records, documents and data is document analysis. Events and facts are questioned [31]. It includes resources such as documents, letters, autobiographies, newspapers, minutes and e-content [32].

\subsection{Collection of Data}

The science and technology course videos analyzed in this research are on 28.07.2017;

http://www.eba.gov.tr/video?\&channel=168\&page=1

http://www.eba.gov.tr/video?\&search=5.\%20s\%c4\%b1

$\mathrm{n} \% \mathrm{c} 4 \% \mathrm{~b} 1 \mathrm{f} \&$ channel $=168$

http://www.eba.gov.tr/video?\&search=ortaokul-6-siniffen-teknoloji\&channel $=168$

http://www.eba.gov.tr/video?\&search=7.\%20s \%c4\%b1 $\mathrm{n} \% \mathrm{c} 4 \% \mathrm{~b} 1 \mathrm{f} \&$ channel $=168$

http://www.eba.gov.tr/video?\&search=8.\%20s\%c4\%b1 $\mathrm{n} \% \mathrm{c} 4 \% \mathrm{~b} 1 \mathrm{f} \&$ channel $=168$

Accessible at internet addresses, 5th grade $(\mathrm{n}=89), 6$ th grade $(n=79), 7$ th grade $(n=147)$ and 8 th grade $(n=118)$, Science and Technology courses are limited to videos. 5, 6, 7 and 8 grade science and technology course videos were watched. Thus, the data is compiled from 433 Science and Technology course videos.

\subsection{Analysis of Data}

A descriptive analysis technique was used to analyze the data in the study. Descriptive analysis is to summarize, interpret and summarize the data within a given system after the data are collected [33]. A causal relationship is established between the data and the results are compared with each other [34].

The videos have been reviewed in the direction of a pre-designed theme. Themes were made while creating themes $[35,36,37,38,39,40]$. The reviews focus on the final 8 questions. In the stages of preparation and evaluation of the questions, expert opinion was applied in the field of Science and Technology. And according to the feedbacks returned, the theme was finalized according to the ideas reached to the common point.

\subsection{Coding and Parsing of Data}

Analyzed 433 Science and Technology videos were followed over and over again. When the videos are viewed, necessary cooling times are left and the negative factors are reduced to the minimum. Questioned items are reduced to sub-problems. For example, while learning areas are being analyzed: live and life, substance and change, physical events, and the Earth and the Universe. While learning strategies are being analyzed: learning through presentation, learning through invention, research and investigation. The videos were first viewed in the direction of the problem cue, then repeatedly viewed and interpreted for each lower step.

After each encoder encodes its own data, the reliability of the encoder is compared by comparing the data of the encoders. When this calculation is made,

$$
\text { Reliability }=\frac{\text { opinion Alliance }}{\text { Opinion Alliance }+ \text { Visibility Separation }} * 100
$$

Analysis is carried out using the following formula [41]. The security between the encoders was found to be $98 \%$. The results obtained were evaluated using the IBM SPSS 24 program. The themes and sub-themes were transferred to the programa respectively and interpreted as the videos were watched. The results of the study were evaluated in the findings section of findings.

\section{Results}

In the findings section, the analysis and the findings are put together in the course of the research, and the problem cues for each sub-theme are interpreted under the tables.

\subsection{How Is the Distribution of Science and Technology Course Videos in EBA According to Classes?}

Table 1. Distribution of Science and Technology Course Videos by Classes

\begin{tabular}{|c|c|c|}
\hline Classroom & $\mathrm{f}$ & $\%$ \\
\hline 5. Classroom Videos & 89 & 20,55 \\
\hline 6. Classroom Videos & 79 & 18,24 \\
\hline 7. Classroom Videos & 147 & 33,95 \\
\hline 8. Classroom Videos & 118 & 27,25 \\
\hline Total & 433 & 100 \\
\hline
\end{tabular}

Table 1 shows the distribution of the Science and Technology course videos in the EBA according to classes. According to this, eighty-nine (20.55\%) of the 433 (four and thirty-three) science and technology lessons were 5th 
grade; seventy-nine videos (18.24\%) sixth grade; one hundred forty-seven videos $(33.95 \%)$ 7th grade; one hundred eighteen videos $(27.25 \%)$ were prepared for the 8 th grade. It is thoughtful that the number of videos prepared for the 8th grade is small compared to the 7 th grade despite the passing of the transition examination.

\subsection{How Long Are the Courses of the Science and Technology Course Videos in EBA?}

Table 2. Distribution of Science and Technology Course Videos by Their Duration

\begin{tabular}{|c|c|c|}
\hline Time & $\mathrm{f}$ & $\%$ \\
\hline Less than 1 minute & 48 & 11,09 \\
\hline $1-5$ minutes & 294 & 67,90 \\
\hline $5-10$ minutes & 82 & 18,94 \\
\hline $10-30$ minutes & 9 & 2,08 \\
\hline
\end{tabular}

Table 2 shows the duration of Science and Technology course videos in EBA. According to this, 433 science and technology lessons in EBA are $48(11.09 \%)$ minutes shorter than one minute, $294(67.90 \%)$ between one minute and five minutes; 82 (18.94\%) between five minutes and ten minutes; $9(2.08 \%)$ are between ten and thirty minutes. 30 minutes and no video above. In particular, it was observed that the majority of the videos were between 1 and 5 minutes.

\subsection{How Is the Distribution of the Science Courses in EBAAccording to the Number of Watched Courses?}

Table 3. Distribution of Science and Technology Course Videos by Number

\begin{tabular}{|c|c|c|}
\hline Views & $\mathrm{f}$ & $\%$ \\
\hline $1-1000$ & 126 & 29,09 \\
\hline $1001-5000$ & 220 & 50,80 \\
\hline $5001-10000$ & 64 & 14,78 \\
\hline $10001-20000$ & 17 & 3,92 \\
\hline $20001-70000$ & 6 & 1,38 \\
\hline
\end{tabular}

Table 3 presents the numbers watched by users of science and technology course videos in EBA. Of the videos, $126(29.09 \%)$ were between one and a thousand times; $220(50.80 \%)$ thousand to one to five thousand; 64 $(14.78 \%)$ between five thousand and ten thousand times; $17(3.92 \%)$ between ten thousand and twenty thousand times; And 6 (1.38\%) were observed between twenty thousand and seventy thousand times. Considering the numbers of teachers, students and other stakeholders in the Turkish Education System, it is thought that the monitoring and effective utilization rates of the videos are low.

\subsection{What Is the Appropriateness of Science and Technology Course Videos in the EBA to the Grade Level in Which the Course Is Taught in Terms of the Distribution of Achievements?}

Table 4. Appropriateness of Grade Levels of Science and Technology Course Videos in terms of Profit Distribution

\begin{tabular}{|c|c|c|}
\hline Appropriateness of Gains to Class Levels & $f$ & $\%$ \\
\hline Appropriate & 403 & 93,07 \\
\hline Inappropriate & 30 & 6,93 \\
\hline
\end{tabular}

Table 4 shows the appropriateness of the Science and Technology course videos in the EBA to the grade level in the network. According to this, $403(93.07 \%)$ of the videos are in accordance with the class level to which they are related, whereas $30(6.93 \%)$ are not related to the related class level. The vast majority of videos are thought to be related to achievements. It has not been specified at which grade level some videos are. This is something that can cause complexity in the system. At the same time, in many video materials, some achievements not included in the science curriculum were included. For example, while only the names of the stages of the mitosis division need to be addressed, some videotapes have referred to the details of these stages.

\subsection{What Topics Are Included in Science and Technology Course Videos in the EBA and Which Learning Areas Are Involved in the Science and Technology Curriculum?}

Table 5. Distribution of Science and Technology lesson videos according to the areas of interest related to the topics covered and their relation to the stated gains

\begin{tabular}{|c|c|c|}
\hline Learning Areas / KNOWLEDGE & $\mathrm{f}$ & $\%$ \\
\hline Live and Life & 161 & 37,18 \\
\hline Substance and Change & 92 & 21,25 \\
\hline Physical Events & 160 & 36,95 \\
\hline Earth and the Universe & 20 & 4,62 \\
\hline
\end{tabular}

Table 5 presents the learning areas where the topics in Science and Technology course videos on EBA are related. According to this, 161 (37.18\%) living things and life from the topics in the videos; $92(21.25 \%)$ of matter and change; 160 (36.95\%) physical events; 20 (4.62\%) of the world and the universe are all related to learning areas, while the target gains in the videos are sometimes related to a single learning field, and sometimes to multiple learning areas at the same time. However, there has been very little mention of the World and the Universe, and there has been an imbalance between learning areas, and there is not much video material for

Science-Technology-Society-Environment, which is an important element of the program. 


\subsection{What Topics Are Included in Science and Technology Course Videos in the EBA and Which Learning Areas Are Involved in the Science and Technology Curriculum?}

Table 6. Distribution of science and technology course videos according to teaching strategies

\begin{tabular}{|c|c|c|}
\hline Teaching Strategies & $\mathrm{f}$ & $\%$ \\
\hline Learning Through Presentations & 223 & 51,50 \\
\hline Learning Through Invention & 210 & 48,50 \\
\hline
\end{tabular}

In Science and Technology course videos in EBA, learning-teaching strategies were utilized not only through teaching through presentation but also through the teaching method of invention and other learning-teaching strategies. The inventive learning videos used here partially reflect this strategy. Learning strategies will be more realistic if they are used to reflect the actions in these videos to the classroom environment. Most of the videos are prepared on the basis of the presentation-based learning strategy and the student is passive in this teaching method [42] In order to actively engage the student, to increase the sense of curiosity and to design efficient learning environments, the learning strategy through invention can be preferred [43]. Students learn through guiding research and investigation [44] and the full learning theory that advocates that all achievements in the school can be gained to the students [45] was not found in the video material.

\subsection{How Is the Distribution of Science and Technology Course Videos in EBAAccording to the Bloom Taxonomy of the Achievements that Students Will Reach?}

Table 7. Distribution of Acquisition of Science and Technology Course Videos by Bloom Taxonomy

\begin{tabular}{|c|c|c|}
\hline Bloom Earnings & $\mathrm{f}$ & $\%$ \\
\hline Recall & 222 & 51,27 \\
\hline Understanding & 171 & 39,49 \\
\hline Application & 39 & 9,01 \\
\hline Analyzing & 0 & 0 \\
\hline Evaluation & 1 & 0,23 \\
\hline Creating & 0 & 0 \\
\hline
\end{tabular}

Table 7 shows the appropriateness of the Science and Technology course videos in the EBA to the bloom taxonomy. According to this: 222 (51.27\%) remembrance steps from the videos; 171 (39.49\%) understanding step; $39(9.01 \%)$ application step and $1(0.23 \%)$ step. No video is available for analysis and creation steps. The Science and Technology course limits the video's reaching its intended goal.

\subsection{Which Teaching Techniques Were Used in the Videos in the EBA?}

Table 8 shows the distribution of teaching techniques used in Science and Technology course videos in EBA. According to this, 185 (42.73\%) narration technique, 17 $(3.93 \%)$ play technique, $3(0.69 \%)$ demonstration technique and $3(0.69 \%)$ short film $(6.93 \%)$ singing technique, $139(32,10 \%)$ experimental technique, 49 $(11,32 \%)$ role playing / drama technique, $3(0.69 \%)$ conference technique, $2(0,46 \%)$ animation technique and $2(0,46 \%)$ debate technique. The use of many techniques in video material is a beautiful development. But the most use of narrative technique is incompatible with the constructivism approach. Especially, most of the techniques are ineffective in giving more superior cognitive properties in the bloom taxonomy, which correspond only to reminiscence and comprehension.

Table 8. Teaching techniques used in Science and Technology Course Videos

\begin{tabular}{|c|c|c|}
\hline Instructional Techniques & $\mathrm{f}$ & $\%$ \\
\hline Expression & 185 & 42,73 \\
\hline Game & 17 & 3,93 \\
\hline Show & 3 & 0,69 \\
\hline Short film & 3 & 0,69 \\
\hline Making Songs & 30 & 6,93 \\
\hline Experiment & 139 & 32,10 \\
\hline Role Playing/ Drama & 49 & 11,32 \\
\hline Conference & 3 & 0,69 \\
\hline Animation & 2 & 0,46 \\
\hline Discussion & 2 & 0,46 \\
\hline
\end{tabular}

\section{Conclusions and Recommendations}

Within the scope of the FATIH project, which started with pilot implementation with the second semester of 2011-2012 academic year, interactive boards, internet network infrastructure, multi-function printer and tablet PCs have been deployed and educational e-content services have been introduced into the education [46]. Useful and reliable educational e-content preparation by MEB will be favorable to our education system [47]. Established for this purpose, EBA is an important breakthrough in this era when education is progressing in parallel with technology. All stakeholders involved in education are an important platform in which they can develop each other in a social relationship. When the videos of the science course in EBA are examined;

1. From the 433 (fourteen thirty-three) Science courses videos in EBA, $89(20.55 \%)$ 5th grade; $79(18.24 \%)$ sixth grade; $147(33.95 \%)$ 7th grade; $118(27.25 \%)$ were prepared for the 8 th grade. It is thoughtful that the number of videos prepared for the 8th grade is small compared to the 7 th grade despite the passing of the transition examination. It is also thought that the 5th and 6th grade videos are not enough. The number of these videos can be increased by providing teacher and student participation. 
2. Of the videos in the EBA, $48(11.09 \%)$ videos less than one minute, $294(67.90 \%)$ were between one minute and five minutes; $82(18.94 \%)$ between five minutes and ten minutes; $9(2.08 \%)$ are between ten and thirty minutes. 30 minutes and no video above. In particular, it was observed that the majority of the videos were between 1 and 5 minutes. Short videos can be used to attract attention and arouse curiosity. For this reason, it is normal that the number of short videos is high. Long videos should be used for in-depth information on a topic. But 30 minutes and a video over it is a shortcoming. Features such as documentary-like long videos can increase the interest of the learner in the course.

3. Of the videos, $126(29.09 \%)$ were between one and a thousand times; $220(50.80 \%)$ thousand to one to five thousand; $64(14.78 \%)$ between five thousand and ten thousand times; $17(3.92 \%)$ between ten thousand and twenty thousand times; and $6(1.38 \%)$ were observed between twenty thousand and seventy thousand times. Considering the numbers of teachers, students and other stakeholders in the Turkish Education System, it is thought that the monitoring and effective utilization rates of the videos are low. There are many advantages to watching a large number of videos. For example, a faulty video can be discovered and corrected immediately. Stakeholders should be encouraged to watch videos more.

4. Of the videos in the EBA, 403 (93.07\%) are in accordance with the class level to which they are associated, whereas $30(6.93 \%)$ are not relevant to the class level. The vast majority of videos are thought to be related to achievements. It has not been specified at which grade level some videos are. This is something that can cause complexity in the system. At the same time, in many video materials, some achievements not included in the science curriculum were included. For example, while only the names of the stages of the mitosis division need to be addressed, some videotapes have referred to the details of these stages.

5. $161(37.18 \%)$ of the subjects in the videos in the EBA are live and life; $92(21.25 \%)$ of matter and change; 160 (36.95\%) physical events; $20(4,62 \%)$ of the world and the universe are all related to learning areas. While the target achievements in the videos are sometimes related to a single learning field, sometimes it can be related to multiple learning areas at the same time. This can be explained by the achievements of Science and its integration with the skills. Nevertheless, the Earth and the Universe are rarely addressed and there is an imbalance between learning areas. In addition, there are not many video materials for

Science-Technology-Society-Environment field which are important elements of the program. It is thought that there should be a equivalent number of videos for each learning area. Especially the "Earth and Universe" unit has gained importance recently. On the other hand, the number of 20 videos is very small.
6. The strategy of learning through presentation and invention through intensive use has been used. There was no learning strategy through research and investigation. Today's education system leads the student to research. It is now important to receive information instead of getting information. Nevertheless, the fact that this strategy is never used is a major drawback. Learning through research and investigation should be widely used. Thus, students can gain scientific process skills. The presentation learning strategy constitutes a large part of the videos. This system, which is in the passive situation of the student, should be abandoned. The student must be active so that they are able to perform more effectively. This strategy should be given less space.

7. Most of the videos are in the recall step according to the bloom taxonomy. A large part of the remaining is the order of understanding. Recall and comprehension step is used to acquire lower level cognitive goals. These steps do not provide metacognitive skills. In order to gain metacognitive skills; synthesis, analysis and evaluation steps should be used. From these steps, only the evaluation step is used and it is only a number. The videos in EBA do not support high-level thinking skills. With these videos, students can simply repeat a concept they are learning. But these videos are not enough for new learning.

The EBA website should be constantly updated with the opinions of the stakeholders; the materials in the content should be enriched and parallelized with the teaching program [48].

Investigating and examining all educational e-content in EBA will benefit the Turkish Education System. In this way, the content of all materials can be enriched and more effective learning environments can be provided.

\section{REFERENCES}

[1] Bolat, Y. The flipped classes and education information network (EIN) Ters yüz edilmiş sınıflar ve eğitim bilişim ă̆1 (EBA). Journal of Human Sciences, 13(2), 3373-3388, 2016.

[2] Filiz, O. ve Kurt, A. A. Flipped learning: Misunderstandings and the truth. Journal of Educational Sciences Research, 5(1), 215-229, 2015.

[3] Brooks J. G.and Brooks, M.G. The case for constructivist classrooms Virginia: ASCD Alexandria, 1993.

[4] Perkins, D. N. The many faces of constructivism. Educational Leadership, Nov., 6-11, 1999.

[5] Fosnot, C. Constructing constructivism. T. M. Duffy and D. H. Jonassen, Constructivism and the Technology of Instruction: A Conversation. New Jersey: Lawrence Erlbaum Associates Publishers, 1992.

[6] Ashgar, 1. Constructivism as substitute for memorization learning: Meaning is created by learner. Education. (116), 16-17, 1995. 
[7] Marlowe, B. and Page M. L. Creating and sustaining the constructivist classroom. USA: Corwin Press, 1998

[8] Erdem, E. Program geliştirmede yapılandırmacı yaklaşım, (Yayımlanmamış Yüksek Lisans Tezi), Ankara: Hacettepe Üniversitesi, 2001.

[9] Azar, A., İrfan, A. P., \& Balkaya, Ö. Çoklu zekâ kuramına dayalı öğretimin öğrencilerin bașarı, tutum, hatırlama ve bilişsel süreç becerilerine etkisi. Hacettepe Üniversitesi Eğitim Fakültesi Dergisi, 30(30), 2006.

[10] M.E.B. Fen ve Teknoloji dersi öğretim programı. Ankara/Turkey: MEB, 2013.

[11] Sönmez, V. Öğretim İlke ve Yöntemleri. Ankara: An1 Yayıncilık, 2007.

[12] Yüksel, S. bilişsel alanın sınıflamasında (taksonomi) yeni gelişmeler ve sinıflamalar. Türk Ĕ̈itim Bilimleri Dergisi, 5(3), 479-511, 2007.

[13] Tutkun, Ö. F., \& Okay, S. Bloom'un yenilenmiş taksonomisi üzerine genel bir bakış. Sakarya University Journal of Education, 1(3), 14-22, 2012.

[14] Tarman, B., \& Kuran, B. Examination of the Cognitive Level of Questions in Social Studies Textbooks and the Views of Teachers Based on Bloom Taxonomy. Educational Sciences: Theory and Practice, 15(1), 213-222, 2015.

[15] Forehand, M. Bloom's Taxonomy: Original and revised. In M. Orey (Ed.), Emerging perspectives on learning, teaching, and technology. Retrieved from http://epltt.coe.uga.edu/index.php?title=Bloom $\% 27$ s_Taxon omy, 2005.

[16] Anderson L. W. \& Krathwohl, D. R. Bloom'un eğitim hedefleri ile ilgili sınıflamasının güncelleștirilmiş biçimi. Durmuş Ali Özçelik (Çev.). Ankara: Pegem Akademi, 2010.

[17] Yılmaz, E., \& Keray, B. Söyleşi metinleri yoluyla sekizinci sınıf öğrencilerinin soru sorma becerilerinin yenilenmiş Bloom Taksonomisine göre incelenmesi, 2013.

[18] Huitt, W. Bloom et al.'s Taxonomy of the Cognitive Domain. Educational Psychology Interactive. Valdosta, GA: Valdosta State University.

http://www.edpsycinteractive.org/topics/cogsys/bloom.html adresinden erişilmiştir (20 Mayıs 2011).

[19] Devlet Planlama Teşkilatı (DPT). Bilgi toplumu stratejisi 2006-2010. Ankara: DPT., 2006.

[20] Millî Eğitim Bakanlığı(MEB). Eğitimde FATíH Projesi web sayfast. Erişim http://FATİHprojesi.meb.gov.tr/tr/index.php, 2015.

[21] MEB. “Temel eğitime destek projesi "öğretmen eğitimi bileşeni” öğretmenlik mesleği genel yeterlikleri”. Tebliğler Dergisi, 2590, 1491-1540, 2006.

[22] Öztan, A. C. Fen ve teknoloji öğretiminde akıllı tahta kullanımının ilköğretim 7. sinıf öğrencilerinin akademik başarılarına etkisi. (Yayımlanmamış Yüksek Lisans Tezi), Necmettin Erbakan Üniversitesi, TÜRKIYYE, 2012.

[23] Koçak, Ö. Fatih projesi kapsamındaki lcd panel etkileşimli tahta uygulamalarına yönelik öğretmen tutumları (Erzincan ili örneği). Yayımlanmamış Yüksek Lisans Tezi, Atatürk Üniversitesi, TÜRKIYYE, 2013.
[24] Gücükoğlu, B., Ceylan, D. Y., \& Dursun, Z. Etkileșimli beyaz tahtalar için arayüz tasarımı ve içerik geliştirme: Millî Eğitim Bakanlığı coğrafya dersi örneği. Retrieved December, 28,2015 .

[25] Tsai, C-C. A Science teacher's reflections and knowledge growth about STS instruction after actual implementation. Science Education. 86 (1). 23-41, 2001.

[26] Aktay, S., \& Keskin, T. Eğitim bilişim aği (eba) incelemesi, 2016.

[27] Keleș, E., Öksüz, B. D., \& Bahçekapili, T. Teknolojinin Eğitimde Kullanılmasına İlişkin Öğretmen Görüşleri: Fatih Projesi Örneği. University of Gaziantep Journal of Social Sciences, 12(2), 2013.

[28] Tüysüz, C., \& Çümen, V. Eba Ders Web Sitesine İlişkin Ortaokul Öğrencilerinin Görüşleri. Uşak University Journal of Social Sciences, 9(27)., 2016.

[29] Pala, F. K., Arslan, H., \& Özdinç, F. Eğitim bilişim aği web sitesinin otantik görevler ve göz izleme ile kullanilabilirliğinin incelenmesi, 2017.

[30] Ateş, M., Çerçi, A., \& Derman, S. (Eğitim bilişim ağında yer alan türkçe dersi videoları üzerine bir inceleme. Sakarya University Journal of Education, 5(3), 105-117., 2015.

[31] Şimsek, H., \& Yıldırım, A. Sosyal bilimlerde nitel araştırma yöntemleri. Ankara: Seçkin Yayıncılık, 2003.

[32] Geray, H. Toplumsal Araştırmalarda Nicel ve Nitel Yöntemlere Giriş (2. baskı). Ankara: Siyasal Kitabevi, 2006.

[33] Şimşek, H., \& Yıldırım, A. (2011). Sosyal bilimlerde nitel araştırma yöntemleri. Ankara: Seçkin Yayıncılık.

[34] Creswell, J.W. Research design: Qualitative, quantitative and mixed method approaches. California: Sage Publications Inc., 2003.

[35] Anıl, D. Uluslararası öğrenci başarılarını değerlendirme programı (PISA)'nda Türkiye'deki öğrencilerin Fen ve Teknoloji başarılarını etkileyen faktörler. Ĕ̌itim ve Bilim, 34(152), 2010.

[36] Coştu, B., Ünal, S., \& Ayas, A. Günlük yaşamdaki olayların fen ve teknoloji öğretiminde kullanılması. Ahi Evran Üniversitesi Kırşehir Eğitim Fakültesi Dergisi, 8(1), 2007.

[37] Toraman, S., \& Bülent, A. L. C. I. Fen ve teknoloji öğretmenlerinin yenilenen fen bilimleri dersi öğretim programına ilişkin görüşleri. EKEV Akademi Dergisi, 56(56), $11-22,2013$

[38] Ayvacı, H. Ş., Bakırcı, H., \& Yıldız, M. Fen ve Teknoloji öğretmenlerinin hizmet içi eğitim uygulamalarına ilişkin görüşleri ve beklentileri. Amasya Üniversitesi Ĕ̆itim Fakültesi Dergisi, 3(2), 357-383, 2014.

[39] Meriç, G., \& Tezcan, R. Fen bilgisi öğretmeni yetiştirme programlarının örnek ülkeler kapsamında değerlendirilmesi (Türkiye, Japonya, Amerika ve İngiltere örnekleri). Balıkesir Üniversitesi Fen ve Teknoloji Enstitüsü Dergisi, 7(1), 62-82, 2016.

[40] Eskicumalı, A., Demirtaş, Z., Gür Erdoğan, D., \& Arslan, S. Fen ve teknoloji dersi ögretim programları ile yenilenen Fen ve Teknoloji dersi öğretim programlarının karşılaştırılması. International Journal of Human Sciences, 11(1), 1077-1094, 
2014.

[41] Miles, M. B., \& Huberman, A. M. Qualitative data analysis: An expanded sourcebook. SAGE, 1994.

[42] Demirel, Ö. Öğretme sanatı. Ankara: Pegem Yayınları, 1999.

[43] Kılıç, G. B. Oluşturmacı fen öğretimi. Kuram ve uygulamada eğitim bilimleri. Haziran, 1, 8-22, 2001.

[44] Arıc1, A. F. Türkçe öğretiminde kullanılan strateji-yöntem ve teknikler. Atatürk Üniversitesi Sosyal Bilimler Enstitüsü Dergisi, 7(1), 299-308, 2006.
[45] Bloom, B. S. İnsan nitelikleri ve okulda öğrenme (çev. D. A. Özçelik). İstanbul: Milli Eğitim Bakanlığı Yayınları, 1998.

[46] Eğitim Bilişim Ağ1, Hakkında (Eğitim Bilişim Ağ (EBA).http://www.eba.gov.tr/hakkimizda tam adresinden 01.08.2017 tarihinde alınmıştır.

[47] Baydaş, Ö., Gedik, N., \& Göktaş, Y. Öğretmenlerin bilişim teknolojileri kullanımı: 2005-2011 y1llarının karş1laştırılması. Hacettepe Üniversitesi Eğitim Fakültesi Dergisi, (28), 28-3-28, 2013.

[48] Altın, H. M., \& Kalelioğlu, F. Fatih projesi ile ilgili öğrenci ve öğretmen görüşleri. Başkent university journal of education, 2(1), 2015. 